\title{
Unveiling the Genomic Landscape of Gastric Cancer Diagnosis, a Snapshot
}

\section{Kanishka Uthansingh ${ }^{1,2}$, Sunil Kumar Agarwala ${ }^{3}$ and Manoj Kumar Sahu',2*}

${ }^{1}$ Department of Gastroenterology and Hepatology, Institute of Medical Sciences and SUM Hospital, Siksha 'O' Anusandhan Deemed to be University, Bhubaneswar, Odisha, India

${ }^{2}$ Molecular Diagnostic and Research Center (MDRC), Institute of Medical Sciences and SUM Hospital, Siksha 'O' Anusandhan Deemed to be University, Bhubaneswar, Odisha, India

${ }^{3}$ Department of Surgical Oncology, Institute of Medical Sciences and SUM Hospital, Siksha 'O' Anusandhan Deemed to be University, Bhubaneswar, Odisha, India

*Corresponding Author: Manoj Kumar Sahu, Professor, Department of Gastroenterology, IMS and SUM Hospital, Siksha O Anusandhan Deemed to be University, Bhubaneswar, Odisha, India.
Received: June 22, 2020

Published: August 24, 2020

(C) All rights are reserved by Manoj Kumar

Sahu., et al.

\begin{abstract}
Gastric cancer (GC) still one of the most prevalent malignancies across the globe. So far, the majority of research studies have not come up with a proper diagnostic and therapeutic approach which may be due to lack of external validation. Attempts have been undertaken but due to methodological shortcomings and insufficient reporting, the breach between biomarker discovery and its clinical use not been explored. So, there should be an improved systematized tunnel of diagnostic marker approach focusing on correct methodology, quality of support, and emphasis on external validation which could have an impact on better clinical diagnosis and prognostication. This review aimed at the early diagnosis of GC through biomarkers and their potential applications in cellular proliferation, apoptosis, and angiogenesis. Moreover, this review highlights the genetic, epigenetic modifications, signaling pathways, and NGS advancement that could identify the novel therapeutic targets as well as noninvasive biomarkers for therapeutic response.
\end{abstract}

Keywords: Gastric Cancer (GC); Helicobacter pylori (H. pylori); Epigenetics; MicroRNAs (MiRNA); Next Generation Sequencing (NGS); Microsatellite Instability (MSI); Biomarker

\section{Introduction}

Cancer is considered a life-threatening disease by being the second cause of death globally [1]. As per the GLOBOCAN 2018 database, 1,033,701 new occurrences of stomach malignant growth and 782,685 gastric diseases related death occurred worldwide in 2015 [2]. Gastric cancer is among the top five cancers and is the major reason of neoplastic mortality across the globe [3].

The gastrointestinal tract is one the most cancer-prone organ of the human body as gastric cancers (GCs) are considered the $4^{\text {th }}$ most prevalent cancer worldwide and is the 2nd major cause of death in developing countries [1]. Basing on the internal anatomic site GC is primarily classified as cardia and non-cardia [4]. Gastric cardia is at the close proximity to the esophagus and thus share factorial characteristics with esophageal adenocarcinoma (EAC). Noncardia malignant growth, otherwise called distal stomach disease is increasingly recognized more [5].

Endoscopic resection is currently acknowledged as a curative alternative for the early GC $[6,7]$ but the diagnosis through endoscopy is an interventional procedure. If we look back to the major risk factors of GC, Helicobacter pylori are a cause of concern, con- 
tributing almost $50 \%$ of all patients across the globe apart from other risk factors [6] hence, it is considered as the Class I carcinogen by WHO and IACR in 1994 [7]. Bunch of studies have demonstrated gastric cancer prevention through $H$. pylori screening and complete eradication, especially in high-risk populations [8]. All the members with positive family history should be screened for $H$. pylori to identify the premalignant lesions and early stage cancer [9]. Interestingly a pilot study from IMS and SUM Hospital showed COX-2 mutation was seen in GC patients with $H$. pylori infection [10]. Many more molecular studies have reported the genetic susceptibility and prognostication as regards to gastric cancer. Amid these, researchers across the globe are trying to identify biomarkers that can be applied in future for the risk of progression to GC and diagnose the lesion at the early stage.

\section{Types of gastric cancer}

According to the etiological classification the upper part of stomach adjoining the esophagus is called cardia and the mid distal stomach is called the non-cardia [11] and the new classification by WHO on tumors of digestive system [12]. Adeno carcinoma is very often found in cardia where esophagus connects to the stomach, followed by antrum and body of the stomach. It has been reported that gastric cardia type may be related to gastro esophageal reflux disease, whereas in the intestinal type, inflammation progress from chronic to atrophic gastritis, intestinal metaplasia, dysplasia and carcinoma. Diffuse type is common among elderly men and is more prevalent among women. Intestinal type with H. pylori infection is associated among majority of people. Moreover, genomic study has classified GC in to four molecular sub types such as microsatellite stable/epithelial-mesenchymal transition, microsatellite instability, microsatellite stable/epithelial/TP53, of GC.

\section{Current diagnostic methods}

Usually in when the patient visits the clinic, physician identifies some symptoms of having gastric cancer such as fatigue, loss of appetite, stomachache, early satiety etc. During upper gastrointestinal endoscopy (UGIE) if any suspicious area found, biopsies obtained for morphological and genetic analysis. White light endoscopy (WLE), Dye-based image-enhanced endoscopy (DBIEE) like chromoendoscopy, equipment-based image enhanced endoscopy like narrow-band imaging (NBI) is used for the detection of GC.

Endoscopy or screening through photofluorography in a large population is not feasible in many countries [13,14]. The above tools are also not very cost-effective in Indian population. To date, few biomarkers developed and some in the process of develop- ment to achieve this goal but the concern is all about specificity and sensitivity. The biological markers developed so far are Pepsinogens, Gastrin-17, MicroRNAs, Cancer autoantibodies, and Volatile markers [15]. A non-invasive diagnostic test for the detection of patients at risk of GC would be urgently needed.

\section{Serum based biomarker}

Several studies aimed to identify a serum-based biomarker for the diagnosis of Gastric adeno carcinoma (GAC). Thirteen proteins were selected as candidate markers by taking a set of $120 \mathrm{GAC}$ and 120 control samples for the development of noninvasive biomarker [16]. Furthermore, it was revealed two panels of combined biomarkers such as epidermal growth factor receptor (EGFR), transthyretin (TTR) regulated upon activation, normally T- expressed and presumably secreted (RANTES) and vitronectin (VN) have been explored.

Developing an appropriate non-invasive biomarker might help in the diagnosis and prognostication of GC [17]. In that manner vascular endothelial growth factor (VEGF), human epidermal growth factor receptor (HER) family, E-cadherin, programmed death-ligand 1(PD-L1) and programmed death-ligand 2(PD-L2), fibroblast growth factor receptor(FGFR), mammalian target of rapamycin(mTOR), are among the emerging biomarkers due to the variations in MET, MSI and microRNA [18].

For early detection of GC, South Korea and Japan do screening of suspected population [19] with Carcinoembryonic antigens (CEA) and Carbohydrate antigen (CA) 19-9 [20]. Another marker CA72-4 is the most widely used, apart from this Monoclonal GC 7 antigen (MG7-Ag) for early detection of GC [21].

There is not so far blood-based specific and sensitive biomarker as of now for routine cancer screening. In immunological perspective, so far developed antigens, CEA, CA 19-9 and cancer antigen 72-4(CA72-4) are also explored for the detection of GC [22].

Next-Generation Sequencing (NGS) method is an emerging molecular biology technique since 1953, thereafter a massive parallel sequencing has been revolutionized in the field of the Molecular science. Apart from NGS, Whole-genome sequencing (WGS), Whole-exome sequencing (WES), RNA-Seq, and Targeted sequencing have been evolved in the molecular pathogenesis of GC. Application of those has been exploited in identifying genetic variations leading to the development of gastric cancer. NGS is cost-effective and faster technology and has offered a more comprehensive and accurate tool for genome analysis [23]. 
Comparison of NGS over Sanger's sequencing in detection of allele frequency 2 to $10 \%$ and 15 to $25 \%$ respectively [24].

A considerable effort has been directed towards advancement in the treatment of gastric cancer. Classical biomarkers used for the diagnosis include CEA and CA-19-9, but they are not used exclusively because of low sensitivity and specificity.

Pathogenesis and prognosis of GC have been identified through protein-protein network interaction and for the retrieval of interacting genes STRING and MCODE have been used to construct the protein interaction network. Module analysis of protein-protein interaction (PPI) network have been performed using MCODE and stem-loop miRNAs of hub genes predicted by miRNA and screened by TCGA.

\section{Genetic and epigenetic alterations in gastric cancer}

Dysprosium of multiple genetic changes and pathways play major roles during the progression of GC. Molecular signaling pathways, such as Wnt (WNT) and Notch Signaling pathways (NOTCH a highly conserved cell signaling system, 4 different receptors i.e. NOTCH 1,2,3 and 4), Sonic hedgehog (SHH signaling is intricate signal transduction), and MYC for apoptosis and cellular transformation play critical role in the pathogenesis of GC [25]. Nuclear factor-kB (NF-kB), epidermal growth factor receptor (EGR) [26] and some epigenetic alterations such as DNA methylation, histone modifications, histone acetylation and histone phosphorylation observed in all type of Cancers. DNA methylation normally takes place at cytosine moiety of CpG dinucleotide and histone, mainly at the N-terminal tail which ultimately affects the interaction of DNA with chromatin-modifying protein.

DNA methylation is observed in $H$. pylori infected gastric mucosa, and its application for GC risk has been suggested by different investigators. The ability to detect small amount of methylated DNA whether from tissues, serum or blood allows using DNA methylation as a molecular marker in GC. Moreover, the integrative analysis on the availed dataset which DNA methylation signature being utilized for the prediction of GC [27].

The advancement of gene methylation as a target for detection and diagnosis of cancer in tissue specimens and body fluids such as serum have greater application in gastric cancer [28]. DNA modification and histone methylations altering the gene expression may be explored in the epigenetic therapy for GC [29]. Several research groups identified instances of both hypermethylation of tumor suppressor genes and global hypomethylation of oncogenes. These modifications in DNA methylation status could be used as biomarkers for the diagnosis and prognosis of cancer patients undergoing chemotherapies. Methylation is dependent upon anticancer drug resistance in patients with GC. It might be a significant epigenetic target for overcoming this problem.

miRNA - Maybe a suitable epigenetic biomarker in early diagnosis of gastric cancer

Various events such as genetic and epigenetics changes take place during the expatiate cataract of carcinogenesis. During gene expression process miRNAs are generally dysregulated in the gastric mucosa during the $H$. pylori infection leads to progression of chronic gastritis, atrophic gastritis, intestinal metaplasia, to dysplasia and invasive cancer [30]. MicroRNAs are a huge group of posttranscriptional controllers of quality articulation that are around 21,24 nucleotides long [31,32]. Several studies have shown that non-coding RNAs like miRNA and IncRNA take a major role in the progression of GC. Most of the literature mentioned, IncRNA regulates cancer progression at the step of transcription and post- transcription level and also by completely mixing with miRNA to promote protein stabilization at the post-transcript level.

The specificity and sensitivity of those developed antigens found to be inadequate for clinical use. So, there is a strong need for developing an optimum biomarker. Pepsinogen I and II (PG I and PG II) correlate with Atrophic gastritis, a preneoplastic condition and they are commonly used in Asian countries. In European countries, PGI and II panels are expanded by Gatrin-17(G17) which is generated by G-cells. But the use of G17 is hindered by the stability of peptide [33]. A meta-analysis revealed the potential role of microRNA-21 in the diagnosis of GC with the pooled sensitivity and specificity, the area under the curve (AUC) is 0.80 [34]. Over expression of MicroRNA-630 is associated with poor overall survival, providing the first evidence that miR-630 expression is an independent prognostic factor and it might be a potentially valuable biomarker for GC [34]. miR sequencing approach detected 5 differentially expressed genes such as miRs, hsa-miR-132-3p, hsamiR-155-5p, hsa-miR-19b-3p, hsa-miR- 204-5p and hsa-miR-30a$3 p$, which were significantly down modulated between the tumoral and peritumoral cancer tissues.

\section{Microsatellite instability (MSI) in detecting gastric cancer}

Microsatellite (MS) is a short Tandem Repeats (STRs) or simple sequence repeats (SSRs) consisting of 1-6 nucleotides. MS is widely distributed and located near the coding region. The mechanism of MS generation is DNA slippage in the process of replication of the 
basic group of declined strand and complementary stand resulting in one or more of the repeating units missing or inserting [35].

With the development of Human Genome Project (HGP), researchers found the association with MSI, which was suggested relevant for the detection of GC. A study shown MSI as a favorable prognostic marker, but it is relevant only in less than 10\% GC [36]. Another study didn't find a significance influence in 429 study subjects. In a meta-analysis involving 1556 patients have shown that MSI as a prognostic marker in respectable GC.

MSI studies have shown that after screening markers have been detected mutant in each of those samples taken and after detecting the wild type it was recommended as a novel panel of biomarker for the detection of GC.

The association indicates that MSI induced by a defect in the DNA mismatch repair gene plays an important role in gastric cancer. Criteria for MSI Compared with the control group, the shift of abnormal bands or bands after electrophoresis is considered as positive MSI. High-frequency MSI (MSI-H) was defined as $30 \%$ - 40\% unstable loci or above, low-frequency MSI (MSI-L) as less than unstable loci however MS-stable (MSS) was defined as no MSI [37].
According to the National Comprehensive Cancer Network Guideline, Microsatellite instability (MSI) is linked with the prognosis of several cancers.

MSI is differentially expressed in Muir-Torre syndrome, mostly expressed with shared pathologically proven patients of colorectal cancer [38]. A high mutational load and a high microsatellite instability or mismatch repair deficiency both appear to be predictive for response to PD-1 immune checkpoint inhibition shown in different studied. MSI was predicted by the presence of novel peaks in tumor tissue compared to control furthermore the second indicator for MSI was the difference in microsatellite length in the provided samples hence Tumors exhibited MSI with two or more markers were defined as MSI positive.

\section{Materials and Methods}

We collected 300 articles from open access sites, various categories, such as original articles starting from demographic studies, global statistics, biomarker studies on GC and few reviews and meta-analysis (Figure 1). Table 1 shows the so far developed biomarkers by taking different specimens, the technique they have applied and the suggestions drawn.

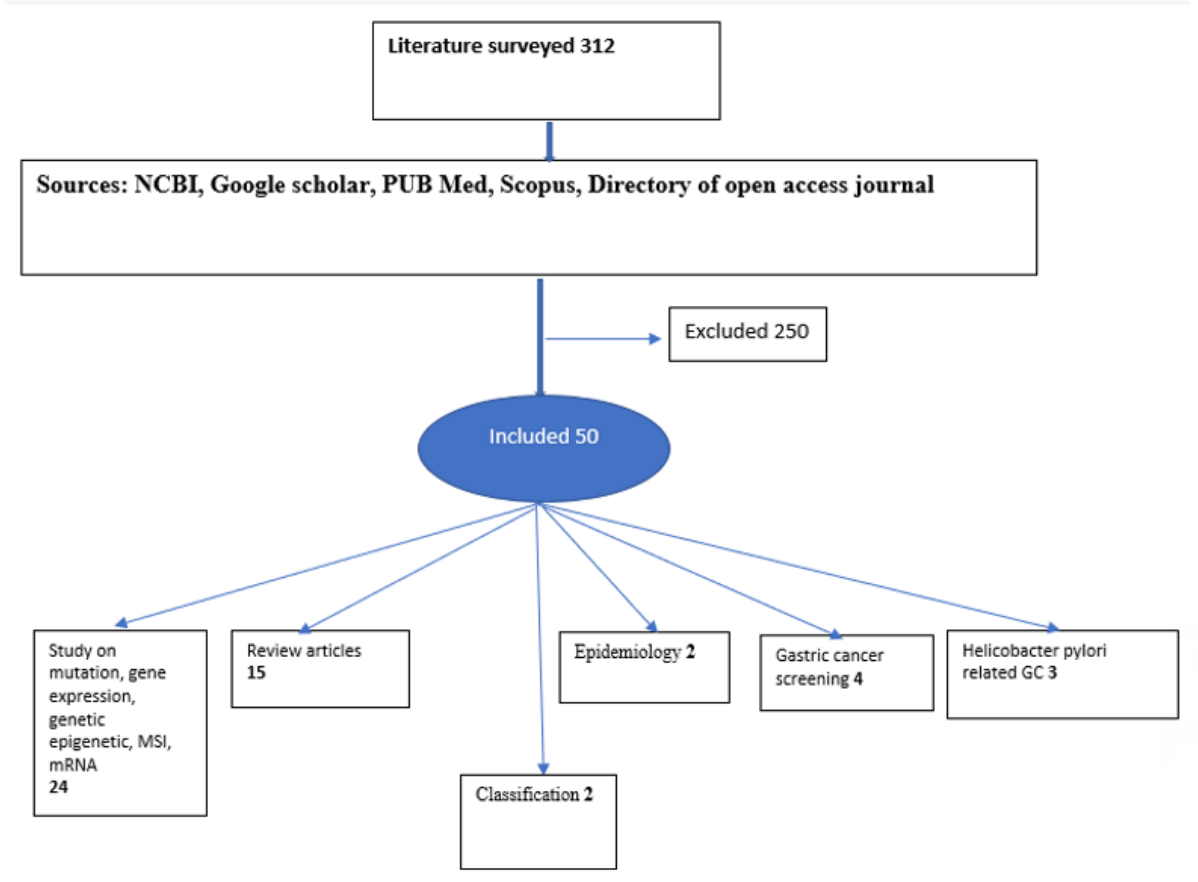

Figure 1: Flow diagram representing Literature search inclusion and exclusion. 


\begin{tabular}{|c|c|c|c|c|c|c|}
\hline Gene Symbol & Gene name & Method of study done & $\begin{array}{c}\text { Effect of Genetic } \\
\text { modification/Major } \\
\text { association with GC }\end{array}$ & $\begin{array}{c}\text { Probable } \\
\text { candidate for } \\
\text { further } \\
\text { application } \\
\end{array}$ & $\begin{array}{c}\text { Specimen } \\
\text { used in the } \\
\text { study }\end{array}$ & Ref \\
\hline HER 2 & $\begin{array}{l}\text { Human epidermal } \\
\text { growth factor } \\
\text { receptor } 2\end{array}$ & $\begin{array}{l}\text { Collected the clinical } \\
\text { variables, Kaplan-Meier } \\
\text { method for analysis }\end{array}$ & No association with GC & \begin{tabular}{|} 
Association of \\
HER 2 with other \\
parameters
\end{tabular} & Tissue & {$[1]$} \\
\hline IncRNAs & $\begin{array}{l}\text { Long non-coding } \\
\text { RNAs }\end{array}$ & $\begin{array}{l}\text { qRT-PCR, Cell culture, CCK-8 } \\
\text { assay, Wound healing assay, } \\
\text { Colony formation assay, } \\
\text { Trans well migration assay, } \\
\text { Glucose uptake assay }\end{array}$ & $\begin{array}{l}\text { Increased expression of } \\
\text { DGCR9 in GC tissues and cell } \\
\text { lines. DGCR9 and lncRNA } \\
\text { significantly co-related }\end{array}$ & $\begin{array}{l}\text { Promotes the } \\
\text { formation of GC }\end{array}$ & Tissue & [3] \\
\hline $\begin{array}{l}\text { EGFR, } \\
\text { proApoA1, } \\
\text { TTR }\end{array}$ & \begin{tabular}{|} 
Epidermal growth \\
factor receptor, \\
pro-apolipoprotein \\
A1, apolipoprotein A1, \\
transthyretin,
\end{tabular} & $\begin{array}{l}\text { Constructed 29-plex array } \\
\text { platform and biomarker } \\
\text { assay }\end{array}$ & $\begin{array}{l}\text { Differentiates the majority } \\
\text { of GC }\end{array}$ & $\begin{array}{c}\text { Panels of } \\
\text { combination bio- } \\
\text { marker }\end{array}$ & $\begin{array}{l}\text { Serum } \\
\text { sample }\end{array}$ & [16] \\
\hline $\begin{array}{l}\text { CEA, CA-19-9, } \\
\text { CA-72-4 }\end{array}$ & \begin{tabular}{|} 
carcinoembryonic \\
antigen (CEA), \\
Carbohydrate antigen \\
(CA) 19-9, \\
Carbohydrate Antigen \\
$72-4$
\end{tabular} & Systemic literature survey & $\begin{array}{c}\text { Prohibited on the } \\
\text { application of CA 19-9, CEA, } \\
\text { and CA 72-4 for screening } \\
\text { and early diagnosis in GC }\end{array}$ & $\begin{array}{c}\text { Diagnostic and } \\
\text { prognostic tumor } \\
\text { marker }\end{array}$ & Clinical data & [20] \\
\hline MG7-Ag & $\begin{array}{c}\text { Gastric cancer } \\
\text {-specific tumor } \\
\text {-associated antigen }\end{array}$ & $\begin{array}{c}\text { Simple and rapid assay } \\
\text { method for early diagnosis/ } \\
\text { Surface plasmon } \\
\text { resonance (SPR) }\end{array}$ & $\begin{array}{c}\text { SPR biosensor has the } \\
\text { potential for diagnosing GC }\end{array}$ & $\begin{array}{l}\text { An early diagnos- } \\
\text { tic marker }\end{array}$ & Serum & [21] \\
\hline mrDEGs & $\begin{array}{c}\text { methylation-related } \\
\text { differentially expres- } \\
\text { sion genes }\end{array}$ & $\begin{array}{l}\text { Identified methylation } \\
\text { differentially expressed } \\
\text { genes in GC, Pathway } \\
\text { enrichment analysis of } \\
\text { mrDEGs }\end{array}$ & $\begin{array}{c}\text { Revealed the information of } \\
\text { biological process related to } \\
\text { initiation and progression of } \\
\text { gastric cancer, developed a } \\
\text { DNA methylation } \\
\text { signature consisting of ten } \\
\text { gene members (SCNN1B, } \\
\text { NFE2L3, CLDN2, RBPMS2, } \\
\text { JPH2, GBP6, COL4A5, } \\
\text { SMKR1, PPP1R14A, and } \\
\text { ARL4D) associating with } \\
\text { cancer recurrence }\end{array}$ & $\begin{array}{l}\text { DNA methyl } \\
\text { signature }\end{array}$ & Tissue & {$[27]$} \\
\hline PGI I \& II & $\begin{array}{l}\text { Serum pepsinogen } \\
\text { I \&II }\end{array}$ & UGIE preparation & $\begin{array}{l}\text { PGI, PGII, and G-17 has no } \\
\text { difference in serum and } \\
\text { plasma }\end{array}$ & $\begin{array}{c}\text { Detection of } \\
\text { atrophic gastritis }\end{array}$ & Tissue & [33] \\
\hline MiR-630 & microRNA-630 & RT-PCR & $\begin{array}{l}\text { miR-630 expression was to } \\
\text { be associated with GC } \\
\text { invasion, lymph node } \\
\text { metastasis, distant } \\
\text { metastasis and TNM stage }\end{array}$ & $\begin{array}{l}\text { prognostic } \\
\text { biomarker }\end{array}$ & Tissue & [34] \\
\hline
\end{tabular}




\begin{tabular}{|c|c|c|c|c|c|c|}
\hline MSI & $\begin{array}{l}\text { Microsatellite } \\
\text { Instability }\end{array}$ & $\begin{array}{l}\text { PCR-SSCP silver staining } \\
\text { technique }\end{array}$ & $\begin{array}{l}\text { microsatellite loci Bat25, } \\
\text { Bat26, D2S123, D5S346 and } \\
\text { D17S250 were detected }\end{array}$ & \begin{tabular}{|} 
MSI may serve as a \\
sensitive \\
diagnostic \\
indicator of gastric \\
cancer.
\end{tabular} & Tissue & [37] \\
\hline gp130/STAT3 & $\begin{array}{c}\text { Glycoprotein } 130 / \\
\text { signal transducer and } \\
\text { activator of } \\
\text { transcription }\end{array}$ & $\begin{array}{c}\text { Helicobacter infection } \\
\text { model, Histology and } \\
\text { immunohistochemistry, } \\
\text { qRT-PCR and Bioinformatic } \\
\text { analysis }\end{array}$ & $\begin{array}{l}\text { Hyperactive gp130-STAT3 } \\
\text { signaling closely links } \\
\text { gastric tumorigenesis with } \\
\text { lymphoid neogenesis, and } \\
\text { while a TLS gene } \\
\text { signature was associated } \\
\text { with advanced gastric } \\
\text { cancer patients }\end{array}$ & Mechanism & Tissue & [42] \\
\hline $\begin{array}{l}\text { HER2, MET } \\
\text { and FOXP3 }\end{array}$ & $\begin{array}{c}\text { Epidermal growth } \\
\text { factor receptor 2, Met } \\
\text { is a proto-oncogene- } \\
\text { c-Met, also called } \\
\text { tyrosine-protein } \\
\text { kinase Met or } \\
\text { hepatocyte growth } \\
\text { factor receptor } \\
\text { (HGFR), is a protein } \\
\text { that in humans is } \\
\text { encoded by the MET } \\
\text { gene, Fork head box } \\
\text { P3 }\end{array}$ & $\begin{array}{l}\text { Immunohistochemistry } \\
\text { analyses }\end{array}$ & $\begin{array}{c}\text { FOXP3 expression was } \\
\text { associated to poorly } \\
\text { differentiated tumors, MET } \\
\text { expression }\end{array}$ & $\begin{array}{l}\text { Role of tissue } \\
\text { differentiation }\end{array}$ & Tissue & [43] \\
\hline СMTM2 & $\begin{array}{l}\text { CKLF-like MARVEL } \\
\text { transmembrane } \\
\text { domain-containing } \\
\text { protein } 2 \text { is a protein } \\
\text { that in humans is } \\
\text { encoded by the } \\
\text { CMTM2 gene }\end{array}$ & $\begin{array}{c}\text { Genomic heterogeneity of } \\
\text { DGC described } \\
\text { Cell line, RT-PCR }\end{array}$ & $\begin{array}{l}\text { Identified a recurrent loss } \\
\text { of heterozygosity (LOH) of } \\
\text { DNA copy numbers at the } \\
\text { 3p12-pcen locus in DGC. }\end{array}$ & $\begin{array}{c}\text { Profile of somatic } \\
\text { mutation }\end{array}$ & Tissue & [44] \\
\hline circRNAs & $\begin{array}{c}\text { Circular RNA } \\
0000181\end{array}$ & $\begin{array}{l}\text { Detected by real-time quan- } \\
\text { titative reverse } \\
\text { transcription-polymerase } \\
\text { chain reaction (qRT-PCR). }\end{array}$ & $\begin{array}{l}\text { Hsa_circ_0000181 levels in } \\
\text { gastric cancer tissues and } \\
\text { plasma from gastric cancer } \\
\text { patients were significantly } \\
\text { decreased than those in } \\
\text { paired adjacent non- } \\
\text { tumorous tissues }(\mathrm{P}<.001) \\
\text { and healthy people }\end{array}$ & Biomarker & $\begin{array}{l}\text { Tissue and } \\
\text { plasma }\end{array}$ & [47] \\
\hline KIR & $\begin{array}{c}\text { Killer cell } \\
\text { immunoglobulin-like } \\
\text { receptors }\end{array}$ & Genotyping of KIR & $\begin{array}{c}\text { Four activating and one } \\
\text { inhibitory gene were } \\
\text { associated with GC: 2DS1, } \\
\text { 2DS3,2DS5, 3DS1 and 2DL5 }\end{array}$ & Mutation & Tissue & [48] \\
\hline $\begin{array}{l}\text { EMT } \\
\text { Signature }\end{array}$ & $\begin{array}{c}\text { Epithelial-mesenchy- } \\
\text { mal transition (EMT) } \\
\text { signature genes }\end{array}$ & $\begin{array}{c}\text { qPCR, Tumor xenograft } \\
\text { experiments, low cytometry } \\
\text { and immunofluorescence } \\
\text { staining }\end{array}$ & $\begin{array}{l}\text { The LGR5-expressing } \\
\text { fraction of CD54+ cells } \\
\text { represents gastric cancer } \\
\text { CSCs. } \\
\text { LGR5 was also positively } \\
\text { associated with stemness } \\
\text { regulators }\end{array}$ & $\begin{array}{l}\text { Showing the best } \\
\text { starting material }\end{array}$ & Tissue & [49] \\
\hline
\end{tabular}




\begin{tabular}{|c|c|c|c|c|c|c|}
\hline $\begin{array}{l}\text { PANDAR } \\
\text { CDKN1A, p53 }\end{array}$ & $\begin{array}{c}\text { P21-associat- } \\
\text { ed ncRNA DNA } \\
\text { damage -activated } \\
\text { Cyclin Dependent } \\
\text { Kinase Inhibitor 1A }\end{array}$ & $\begin{array}{c}\text { IncRNA microarray analysis, } \\
\text { northern blot analysis and } \\
\text { qRT-PCR analysis. } \\
\text { Deletion of PANDAR was } \\
\text { conducted using the } \\
\text { CRISPR/Cas9 system for } \\
\text { PANDAR }\end{array}$ & $\begin{array}{l}\text { Upregulated PANDAR in } \\
\text { GC patients was positively } \\
\text { correlated with increased } \\
\text { tumor size, advanced TNM } \\
\text { classification and a poor } \\
\text { survival rate in GC patients. }\end{array}$ & $\begin{array}{c}\text { Prognostic and } \\
\text { therapeutic } \\
\text { marker }\end{array}$ & Tissue & [50] \\
\hline
\end{tabular}

Table 1: Major compounds targeted as candidate marker for diagnosis, prognosis and therapeutic approach for GC by using various specimens.

\section{Discussion and Conclusion}

With the Global screening experience and epidemiological studies from 185 countries, there is decline of GC, but due to various factors the incidence rate varies in different countries.

H. pylori infection is one of the factors playing the key role for gastric carcinogenesis, eradication in fact deceases the incidence of GC. Apart from H. pylori, Epstein barr virus may be a causation factor for gastric cancer. Dysregulation of the intrinsic survival response to H. pylori infection evolves as the major culprit in disease progression, so the most relevant adaptive mechanisms triggered are endoplasmic reticulum stress and protein unfolding response, autophagy, oxidative stress and inflammation leading to precancerous lesions. It is suggested that $H$. pylori infection may contribute to GC risk by affecting DNA damage of Lgr5-positive epithelial stem cells [39]. Effectively one clinical trial suggested that $H$. pylori eradication reduces risk, who has history of GC in first-degree relatives.

Though the surgical intervention is declining in the present scenario, still laparoscopic gastrectomy is done with neoadjuvant or subsequent adjuvant therapies.

Few pathway analyses have shown that, Molecular signaling such as beta pathway on hedgehog signaling may lead to tumorigenesis $[25,26]$. PI3K/AKT/mTOR signaling pathways and NKX6, a transcription factor for Wnt/ $\beta$-catenin and Rho-GTPase signaling-related genes play key role for carcinogenesis [40,41]. gp130STAT3 signaling closely links gastric tumorigenesis with lymphoid neogenesis but it did not indicate a favorable prognosis for GC [42]. The association among HER2, MET and FOXP3 expression highlights the role of tissue differentiation in gastric adenocarcinoma [43] and identification of genomic aberrations associated with lymph node metastasis in diffuse-type GC provides profiles of somatic mutations and DNA copy numbers [44]. Likewise, intraperitoneal TAMs are expected to be a promising target in the treatment of peritoneal dissemination in gastric cancer [45]. Again, Interaction between CD133 and PI3K-p85 promotes by Tissue and plasma hsa_circ_0000181 and circ-RNA 0000181 both may be a novel biomarker for the screening and diagnosis of GC $[46,47]$. Polymorphisms in KIR genes suggests mutated NK cells may contribute to GC development by increasing gastric mucosa inflammation [48] moreover, TCGA acts as cell-cycle-associated genes providing the prognostic value of in gastric adenocarcinoma.

Mutational review suggested that TP53 gene, ubiquitin protein ligase E3A, PI3K/AKT/mTOR signaling pathway gene polymorphism and IL-17A rs2275913 and IL-17F rs763780 are the risk of potential development of GC.

Matrix metalloproteinase-1 (MMP-1) promoter, ERCC5 and TP53 polymorphisms are well linked with distal gastric malignancy in eastern Indian as well as other countries. It is also seen that precancerous gastric lesion with $H$. pylori infection, vacA+, bab2+ and oipA+ genotype increase the risk of GC. Moreover, 758GA polymorphism of 3'untranslated region associates with increased risk.

Identification of potential key genes with prognostic value associated with the pathogenesis and prognosis of gastric cancer based on integrated bioinformatics analysis. Moreover, it was characterized that Sphere cells are the best starting materials CSCs with signature genes NANOG, NANOGP8, PRRX1, TWIST1, and BMI1 [49].

Reviews and meta-analysis have showed that DNA methylation can acts as a non-invasive biomarker for the detection of all cancers as well GC for targeted epigenetic therapy. It has been shown that MLH1 methylation is an alive biomarker for the prediction of GC. Epigenetic changes potentially useful for early diagnosis because of the changes and the progression of cancer, may be a potential therapeutic approach. Furthermore, whole of the historical and current approaches to the satellite DNA give us a broad view of the function and its role in chromosomal evolution. 
There been extensive understanding for MSI in genomics and the universal application in microbiology. High-MSI related with programmed death ligand 1 for the prediction of immunotherapy that should be known by the Oncologists has been reported previously. Moreover, reviews and meta-analysis suggested that MSI is a robust prognostic marker which can be utilized for new treatment approach. T.697P detection of MSI with a novel panel of biomarkers to assess the efficacy of postoperative adjuvant chemoradiotherapy, furthermore MSI and altered expression of MLH1 and MSH2 all suggest that MSI may serve as a sensitive diagnostic indicator of gastric cancer.

The serum biomarker panel, Carbohydrate Antigen 19-9, Carbohydrate Antigen 72-A are one of the novel biomarkers been used as a diagnostic marker for GC [16,20], even carcinoma-associated antigen MG7-Ag in human serum also for detection of gastric cancer. PGI, PGII, and G-17 being suggested as the Non-invasive parameters in the detection of atrophic gastritis [33]. For validating diagnostic, prognostic, predictive marker for the early detection $[17,18]$, clinical validation is urgently needed for the specificity.

It has been noticed that highly expressed lncRNA increased the risk of GC, moreover, IncRNA PANDAR blocks CDKN1A gene transcription by interacting with p53 protein [50].

Meta-analysis revealing the role of miRNA and IncRNA as potential biomarker for early detection of GC [30]. In vivo study revealed that MEG3/miR-21 axis affects the cancer growth and metastasis through inhibiting EMT. MiRNA-148, miRNA-200, miRNA-181c, miRNA-630, miR-19a/b and MeCP2 expression signatures serve as tumor suppressor in human [34] and furthermore it was predicted to validate post-transcriptional regulation of miRNAs in different cancers. miRNA being another foot print for the use of reliable non-invasive tool for diagnosis treatment and progression of GC [32]. As mentioned above epigenetic factors and several transcriptional factors may also contribute the dysregulation of miR-23 in cancer.

Various reviews suggested that NGS based WGS, WES, RNA sequence and targeted sequencing may depict the molecular pathogenesis and development of potential biomarker for the treatment of gastric cancer $[23,34]$. Targeted next generation sequencing identifies markers of response to PD-1 blockade.

Network Analysis has shown common tumor biomarker and CEA for the early diagnosis of GC. Combine analysis of in vitro and in vivo studies have shown that GLI1-mediated regulation responsible for drug resistance in GC.

In modern pharmacology, prediction of lack of response to chemotherapy and the mechanism underlying for the failure of the drug to be known, that may guide to design the proper treatment based on immune checkpoint blockade, moreover drug resistance of cancer chemotherapy may cause by decreased antitumor drug uptake, modified drug target, altered cell cycle check point and DNA damage [30].

Non-invasive diagnostic biomarker helps to identify the early stage of gastric cancer and thus improve therapeutic response. Unfortunately, so far there are no specific and sensitive screening biomarkers available. Currently available therapeutic approaches have lot of limitations by the nature of this disease. Distinct genetic and epigenetic events occur during multi-factorial stages leading to carcinogenesis, so the non-invasive biomarker which is more specific and sensitive has to be implemented in clinical practice for the prediction of tumour behaviour. MicroRNAs (miRNAs) mediated endogenous gene regulation are commonly deregulated in the gastric mucosa during the $H$. pylori infection, in a stepwise manner viz. chronic gastritis, preneoplastic conditions such as atrophic gastritis and intestinal metaplasia, early dysplasia leading to invasive cancer [30]. In future tremendous effort need to put to create a foundation for the exploration and development of an effective and non-invasive biomarker for early diagnosis of gastric cancer, from the biospecimens like blood, urine, and stool. This might help to develop the genetic signature of GC. It is urgently needed to develop a biomarker that is conventional, non-invasive, highly specific, capable of early detection of GC ultimately bringing a well treatment choice for the upper and lower economic group of people to overcome the interventional procedures with associated morbidities. Ideal biomarkers for early detection of cancer should be upregulated in the majority of patients with a high level in cancerous tissues and other samples such as serum, saliva and blood. Multinational studies are needed with adequate sample size to develop the diagnosis signature for early treatment of GC. Clinical trials are needed to confirm the specificity and sensitivity of the biomarkers otherwise those will remain in the literature only.

\section{Acknowledgement}

We thank to the president Prof Manojranjan Nayak, Siksha 0 Anusandhan Deemed to be University for providing us the opportunity to undertake the work. 


\section{Conflict of Interest}

No potential conflict of interest relevant to this article was reported.

\section{Funding}

This study was supported by PhD fellowship Grant and is a part of Ph.D. thesis University-Siksha O Anusandhan Deemed to be University Ph. D fellowship Grant No-1781611005/2017.

\section{Bibliography}

1. Feizy A., et al. "HER2 Expression Status and Prognostic, Diagnostic, and Demographic Properties of Patients with Gastric Cancer: a Single Center Cohort Study from Iran". Asian Pacific Journal of Cancer Prevention 19 (2018): 1721-1725.

2. Bray F., et al. "Global cancer statistics 2018: GLOBOCAN estimates of incidence and mortality worldwide for 36 cancers in 185 countries". CA: A Cancer Journal for Clinicians 68 (2018): 394-424.

3. Ni C., et al. "Role of Digeorge syndrome critical region gene 9, a long noncoding rna, in gastric cancer". Onco Targets and therapy 11 (2018): 2259-2267.

4. Mukaisho K., et al. "Two distinct etiologies of gastric cardia adenocarcinoma: interactions among $\mathrm{pH}$, Helicobacter pylori, and bile acids". Frontiers in Microbiology 6 (2015): 1-7.

5. Rawla P and Barsouk A. "Epidemiology of gastric cancer: global trends, risk factors and prevention". Przeglad Gastroenterologiczny 14 (2019): 26-38.

6. Zhou D., et al. "Combining multi-dimensional data to identify a key signature (gene and miRNA) of cisplatin-resistant gastric cancer". Journal of Cellular Biochemistry 119 (2018): 69977008.

7. Moss SF. "The clinical evidence linking Helicobacter pylori to gastric cancer". Cellular and Molecular Gastroenterology and Hepatology 3 (2017): 183-191.

8. Cheung KS., et al. "Risk of gastric cancer development after eradication of Helicobacter pylori". World Journal of Gastrointestinal Oncology 10 (2018): 115-123.

9. Choi IJ., et al. "Family history of gastric cancer and Helicobacter pylori treatment". New England Journal of Medicine 382 (2020): 427-36.
10. Uthansingh K., et al. "COX-2 and CYP2C9 polymorphism and the risk of gastric cancer in the population of Odisha". Journal of Gastroenterology and Hepatology 34 (2019): 258.

11. Chen J., et al. "Expression and Significance of MyD88 in Patients With Gastric Cardia Cancer in a High-Incidence Area of China". Frontiers in Oncology 10 (2020): 1-9.

12. Nagtegaal ID., et al. "The 2019 WHO classification of tumours of the digestive system". Histopathology 76 (2020): 182-188.

13. Leja M., et al. "Implementation of gastric cancer screening-the global experience". Best Practice and Research Clinical Gastroenterology 28 (2014): 1093-106.

14. Choi KS., et al. "Performance of different gastric cancer screening methods in Korea: a population-based study". PLoS One 7 (2012): 1-8.

15. Yada T., et al. "The current state of diagnosis and treatment for early gastric cancer". Diagnostic and Therapeutic Endoscopy 2013 (2013): 1-9.

16. Ahn HS., et al. "Serum biomarker panels for the diagnosis of gastric adenocarcinoma”. British journal of Cancer 106 (2012): 733-739.

17. Mi L., et al. "Prognostic biomarker in advanced gastric cancer". Translational Gastrointestinal Cancer 5 (2016): 16-19.

18. Abbas M., et al. "Current and future biomarkers in gastric cancer". Biomedicine and Pharmacotherapy 103 (2018): 1688-700.

19. Moon JS. "Screening Upper Endoscopy for Early Detection of Gastric Cancer". Journal of Korean Medical Science 33 (2018): 1-2.

20. Kotzev AI and Draganov PV. "Carbohydrate Antigen 19-9, Carcinoembryonic Antigen, and Carbohydrate Antigen 72-4 in Gastric Cancer: Is the Old Band Still Playing?" Gastrointestinal Tumors 5 (2018): 1-3.

21. Fang X., et al. "Detection of gastric carcinoma-associated antigen MG7-Ag in human sera using surface plasmon resonance sensor". Cancer Epidemiology 34 (2010): 648-651.

22. Shimada H., et al. "Clinical significance of serum tumor markers for gastric cancer: a systematic review of literature by the Task Force of the Japanese Gastric Cancer Association". Gastric Cancer 17 (2014): 26-33. 
23. Behjati S and Tarpey PS. "What is next generation sequencing?" Archives of Disease in Childhood - Education and Practice 98 (2013): 236-238.

24. Verma R and Sharma PC. "Next generation sequencing-based emerging trends in molecular biology of gastric cancer". American Journal of Cancer Research 8 (2018): 207-225.

25. Pelullo M., et al. "Wnt, Notch, and TGF- $\beta$ pathways impinge on Hedgehog signaling complexity: an open window on cancer". Frontiers in Genetics 10 (2019).

26. Molaei F., et al. "Molecular signaling in tumorigenesis of gastric cancer". Iranian Biomedical Journal 22.4 (2018): 217.

27. Peng Y., et al. "A DNA methylation signature to improve survival prediction of gastric cancer". Clinical epigenetics 12 (2020): $1-16$.

28. Qu Y., et al. "Gene methylation in gastric cancer". Clinica Chimica Acta 424 (2013): 53-65.

29. Zeng XQ., et al. "Methylation modification in gastric cancer and approaches to targeted epigenetic therapy". International Journal of Oncology 50 (2017): 1921-1933.

30. Link A and Kupcinskas J. "MicroRNAs as non-invasive diagnostic biomarkers for gastric cancer: Current insights and future perspectives". World Journal of Gastroenterology 24 (2018): 3313-329.

31. Si W., et al. "The role and mechanisms of action of microRNAs in cancer drug resistance". Clinical Epigenetics 11 (2019): 1-24.

32. Xu X., et al. "miRNA: The nemesis of gastric cancer". Oncology letters 6 (2013): 631-641.

33. Goni E., et al. "Influence of laboratory-related and endoscopyrelated factors on the assessment of serum pepsinogens and gastrin-17". European Journal of Gastroenterology and Hepatology 29 (2017): 1340-1345.

34. Chu D., et al. "Increased microRNA-630 expression in gastric cancer is associated with poor overall survival". PloS one 9 (2014): 1-5.

35. Saeed AF., et al. "Microsatellites in pursuit of microbial genome evolution". Frontiers in Microbiology 6 (2016): 1-15.
36. Ratti M., et al. "Microsatellite instability in gastric cancer: molecular bases, clinical perspectives, and new treatment approaches". Cellular and Molecular Life Sciences 75 (2018): 4151-4162.

37. Li B., et al. "Detection of microsatellite instability in gastric cancer and dysplasia tissues". International Journal of Clinical and Experimental Medicine 8 (2015): 21442-447.

38. RajanKd A., et al. "DNA mismatch repair defects and microsatellite instability status in periocular sebaceous carcinoma". American Journal of Ophthalmology 157 (2014): 640-647.

39. Uehara T., et al. "H. pylori infection is associated with DNA damage of Lgr5-positive epithelial stem cells in the stomach of patients with gastric cancer". Digestive Diseases and Sciences 58 (2013): 140-149.

40. Yoon JH., et al. "NKX6. 3 is a transcription factor for Wnt/ $\beta$ catenin and Rho-GTPase signaling-related genes to suppress gastric cancer progression". EBioMedicine 9 (2016): 97-109.

41. Qi L., et al. "Study on the association between PI3K/AKT/mTOR signaling pathway gene polymorphism and susceptibility to gastric cancer". Journal of BUON 22 (2017): 1488-1493.

42. Hill DG., et al. "Hyperactive gp130/STAT3-driven gastric tumourigenesis promotes submucosal tertiary lymphoid structure development". International Journal of Cancer 143 (2018): 167-178.

43. Neves Filho EH., et al. "The association among HER2, MET and FOXP3 expression and tumor regression grading in gastric adenocarcinoma”. Apmis 126 (2018): 389-395.

44. Choi JH., et al. "Identification of genomic aberrations associated with lymph node metastasis in diffuse-type gastric cancer". EXperimental and Molecular Medicine 50 (2018): 1-11.

45. Yamaguchi T., et al. "Tumor-associated macrophages of the M2 phenotype contribute to progression in gastric cancer with peritoneal dissemination". Gastric Cancer 19 (2016): 10521065.

46. Song S., et al. "Interaction between CD133 and PI3K-p85 promotes chemoresistance in gastric cancer cells". American Journal of Translational Research 10 (2018): 304-314. 
47. Zhao Q., et al. "Clinical values of circular RNA 0000181 in the screening of gastric cancer". Journal of Clinical Laboratory Analysis 32 (2018): 1-6.

48. Hedayatizadeh Omran A., et al. "Association of P53 gene polymorphism with gastric cancer in Northern Iran as a high risk region". Biomedical Reports 8 (2018): 433-438.

49. Wang B., et al. "LGR5 is a gastric cancer stem cell marker associated with stemness and the EMT signature genes NANOG, NANOGP8, PRRX1, TWIST1, and BMI1". PLoS One 11 (2016): $1-21$.

50. Liu J., et al. "Long noncoding RNA PANDAR blocks CDKN1A gene transcription by competitive interaction with $\mathrm{p} 53$ protein in gastric cancer". Cell Death and Disease 9 (2018): 1-3.

\section{Assets from publication with us}

- Prompt Acknowledgement after receiving the article

- Thorough Double blinded peer review

- Rapid Publication

- Issue of Publication Certificate

- High visibility of your Published work

Website: www.actascientific.com/

Submit Article: www.actascientific.com/submission.php

Email us: editor@actascientific.com

Contact us: +919182824667 